\title{
Ginger and Its Derivatives as Promising Alternatives to Antibiotics in Poultry Feed
}

\author{
Mohamed E. Abd El-Hack ${ }^{1, *(\mathbb{D}}$, Mahmoud Alagawany ${ }^{1, * \mathbb{C}}$, Hazem Shaheen ${ }^{2} \mathbb{D}$, Dalia Samak ${ }^{3}$, \\ Sarah I. Othman ${ }^{4}$, Ahmed A. Allam ${ }^{5}$, Ayman E. Taha ${ }^{6}{ }^{\circledR}$, Asmaa F. Khafaga ${ }^{7}$, Muhammad Arif ${ }^{8}$, \\ Ali Osman ${ }^{9}{ }^{\circledR}$, Ahmed I. El Sheikh ${ }^{10}$, Shaaban S. Elnesr ${ }^{11}{ }^{(1)}$ and Mahmoud Sitohy ${ }^{9}$ (i) \\ 1 Department of Poultry, Faculty of Agriculture, Zagazig University, Zagazig 44511, Egypt \\ 2 Department of Pharmacology, Faculty of Veterinary Medicine, Damanhour University, \\ Damanhour 22511, Egypt; dr_hazemshaheen3010@yahoo.com \\ 3 Department of Veterinary Forensic Medicine and Toxicology, Faculty of Veterinary Medicine, \\ Damanhour University, Damanhour 22511,Egypt; dalia_samak@vetmed.dmu.edu.eg \\ 4 Biology Department, Faculty of Science, Princess Nourah bint Abdulrahman University, \\ Riyadh 11671, Saudi Arabia; sialothman@pnu.edu.sa \\ 5 Department of Zoology, Faculty of Science, Beni-suef University, Beni-suef 65211, Egypt; \\ allam1081981@yahoo.com \\ 6 Department of Animal Husbandry and Animal Wealth Development, Faculty of Veterinary Medicine, \\ Alexandria University, Edfina 22578, Egypt; Ayman.Taha@alexu.edu.eg \\ 7 Department of Pathology, Faculty of Veterinary Medicine, Alexandria University, Edfina 22758, Egypt; \\ Asmaa.Khafaga@alexu.edu.eg \\ 8 Department of Animal Sciences, College of Agriculture, University of Sargodha, Punjab 40100, Pakistan; \\ arif.inayat@uos.edu.pk \\ 9 Department of Biochemistry, Faculty of Agriculture, Zagazig University, Zagazig 44511, Egypt; \\ ali_khalil2006@yahoo.com (A.O.); mzsitohy@hotmail.com (M.S.) \\ 10 Department of Public Health, Faculty of Veterinary Medicine, King Faisal University, \\ Hofuf 31982, Saudi Arabia; aelsheikh@kfu.edu.sa \\ 11 Department of Poultry Production, Faculty of Agriculture, Fayoum University, Fayoum 63514, Egypt; \\ ssn00@fayoum.edu.eg \\ * Correspondence: m.ezzat@zu.edu.eg (M.E.A.E.-H.); dr.mahmoud.alagwany@gmail.com (M.A.)
}

Received: 6 January 2020; Accepted: 25 February 2020; Published: 9 March 2020

Simple Summary: The present review updates the current knowledge about the beneficial effects of ginger and its derivatives as feed supplements to poultry feed, particularly its positive effects on the body weight, carcass traits, egg production and quality, reproductive performance, blood parameters, egg and meat quality and microbiological aspects as well as the economic efficiency.

Abstract: Poultry enterprises have sustained rapid development through the last three decennaries. For which reason, higher utilization of antibacterial, either as therapeutic or growth promoting agents, has been accepted. Owing to the concern of developing bacterial resistance among populations towards antibiotic generations, accumulation of antibacterial remaining's in chicken products and elevating shopper request for outcomes without antibacterial remaining's, looking for unconventional solutions that could exchange antibacterial without influencing productiveness or product characters. Using natural alternatives including ginger, garlic prebiotics, organic acids, plant extracts, etheric oils and immune stimulants have been applied to advance the performance, hold poultry productiveness, prevent and control the enteric pathogens and minimize the antibacterial utilization in the poultry production in recent years. The use of a single replacement or ideal assemblage of different choices besides good supervision and livestock welfare may play a basic role in maximizing benefits and preserving poultry productiveness. The object of this review was to support an outline of the recent knowledge on the use of the natural replacements (ginger and its derivatives) in poultry feed as 
feed additives and their effects on poultry performance, egg and meat quality, health as well as the economic efficiency.

Keywords: Ginger; microbial effect; chemical composition; body weight; carcass weight; birds

\section{Introduction}

On the present day, the non-controlled utilization of antibacterial agents in poultry feed is exposed to critical problems. There are critical factors that prohibit the usage of antibacterial agents such as the drug remaining in chicken meat as well as the drug resistance among bacterial populations. These outcomes have seriously controlled their usage in different nations owing to involvements associated with the spread of antibacterial-tolerant human pathogens and judicial achievement to control their usage in apparent many different nations [1-5]. A perfect prohibiting move on antibiotic usage in poultry feed was conducted into action on the 1st of January 2006 by way of the European Uniting Community; so, entirely of the antibacterial agents prescribed in sub-treating levels for growing promotion purposes (as antibacterial growing promotions, AGP's) were detached [6]. For defeating the unfavorable productiveness and the expand susceptibleness to infections that originate from the withdrawal of antibacterial agents from chicken' feeds, trials have been carried out to look for other practical alternatives. Feed supplements could be either nutritive or non-nutritive compounds that modulate the nutritive material accessibility in the feed finally lowering the expense of feed. As a substitute for the synthetic growth promoters, standard originated growing promoters like probiotics, prebiotics, botanical substances, and enzymes can be utilized to feed additives of the broiler chicken [7-9]. Usage of growth promoting agents of valid sources such as yeast cultivations, prebiotics, probiotics, enzymes, organic acids, botanically involved essential oils and extracts of some spices and herbs consequently appeared of interest in modern years [10-16]. Ginger rhizome (Zingiber officinale) was utilized as a delicacy spice or remedy. The usage of ginger as an alternative for antibacterial growth promoting agent is advantageous for the greater productiveness of poultry, improved appetite and palatability of feed, nutrient absorption, and advanced of gastric enzymes flow [17]. Either antibiotics or synthetic components totally utilized as feed add-on in livestock feed are under discussion since their probable toxicological impacts. In addition, there is an advancing direction of natural originated products for the purpose of reducing the usage of synthetic compounds [18]. So, medicinal herbs or their derivatives are presently believed intact and provide an achievable choice to fulfill customer needs and prevalent market contests $[19,20]$.

Zingiber officinale Roscoe, relating to the Zingiberaceae family, commonly recognized as ginger, is a monocotyledonous herbaceous herb and one of the topmost popular feed-flavoring additive managed worldwide [21] Lately, various pharmacological characters of ginger, such as analgesic, anti-inflammatory, gastrointestinal modulating agent, antimicrobial and antioxidant characters have been mentioned [22]. Ginger could be a possible choice for popular synthetic growth promoting agents like antibacterials [23]. The featured ginger sense originated from the inconstant substances that composed of gingerols, shogaols and zingrone [24]. This review article aimed to shedlight the impacts of ginger or its derivatives as natural alternatives on growth performance, carcass characters, egg production and quality, reproductive performance, nutrient digestibility, immune response, some blood biochemical values, egg and meat quality and microbiological aspects of birds.

\section{The Effect of Ginger Oil}

Ginger oil was originated from Z. officinale roots, which its components influenced according to the geographical area, roots condition and extraction protocols (freshness or dryness). The antifungal, antibacterial, anti-inflammatory, analgesic and immunomodulatory impacts of ginger oil have been distinguished in preclinical trials [25]. The harmlessness concerns of ginger oils are well-mentioned 
and are usually considered of being safe. By reason of broad pharmacological impacts of ginger oil, considerations to such element of valid combinations in the control of respiratory and gastrointestinal affections are of great importance.

\section{Chemical Composition of Ginger Extract}

Chemical components of ginger oil beside its potential anti-inflammatory and antioxidant were documented [26]. The major elements as discovered via Gas Chromatography-Mass Spectrometry (GC-MS) method were zingiberene which represented as $31 \%$ of the total area, curcumene $(15.4 \%)$ and then sesquiphellandrene (14.02\%). Ginger oil collected superoxide, hydroxyl and $\alpha$, $\alpha$-diphenyl- $\beta$-picrylhydrazyl (DPPH) radicals so, minimized tissue in vitro fat peroxidation. Ginger oil intraperitoneal inoculation caused inhibition of phorbol12-myristate-13-acetate initiated superoxide chemicals released by macrophages. While, oral application of ginger oil for at least 30 days, critically improved glutathione reductase, glutathione and superoxide dismutase (SOD) values [26]. Ginger oil's product is altered from 1.0 to $3 \%$, depending on the source of rhizomes [27]. Additionally, to the obtained essential oil's, the chemical composition of ginger oils are influenced by the origin of rhizome, freshness or dehydration and extraction procedures.

Singh et al. [28] extracted basic oil from Zingiber officinale fresh roots and described GC-MS protocol of the basic oil. They mentioned the presence of 69 ingredients, calculating for $96.93 \%$ of the whole oil. The vital ingredient was zingiberene $(28.62 \%)$ then camphene $(9.32 \%)$, then curcumene $(9.09 \%)$ and finally $\beta$-phellandrene (7.97\%). Analysis of the oleoresin mentioned the existence of 34 ingredients, measuring for $88.63 \%$ of the whole oleoresin. The critical ingredients were trans-6-shogaol (26.23\%), trans-10-shogaol (13.0\%), $\alpha$-zingiberene (9.66\%) and 10-gingerdione (6.80\%). Furthermore, the basic oil was discovered to be $100 \%$ Fusarium oxysporum antifungal effect, while at the same time, oleoresin showed 100\% antifungal in contact with Aspergillus niger. The foregoing showed advanced antioxidant action in sunflower oil in comparison with the basic oil or synthetic antioxidants (BHT and BHA). In addition, Sharma et al. [29] analyzed basic oil extracted from the raw roots of Z. officinale collected from Ghaziabad area in order to assess its antimicrobial action. The fresh roots were exposed to hydrodistillation to obtain the basic oil content which was analyzed by either GC or GC-MS protocols. The extracted oil was assessed for antimicrobial action by disc diffusion technique. Data showed that the extracted basic oil was distinguished by a high proportion of sesquiterpenes $(66.66 \%)$ then monoterpenes $(17.28 \%)$ and aliphatic ingredients $(13.58 \%)$ as presented in Figure 1 . The major sesquiterpene components (Figure 2 ) were zingiberene $(46.71 \%)$ then valencene $(7.61 \%), \beta$-funebrene $(3.09 \%)$ and selina-4(14),7(11)-diene (1.03\%). Additionally, monoterpenes were distinguished as citronellyl n-butyrate (19.34\%) then $\beta$-phellandrene $(3.70 \%)$, camphene $(2.59 \%)$ and $\alpha$-pinene $(1.09 \%)$. Also, Sasidharan et al. [30] discovered that inconstant oils came from two topmost prevailing cultivars from Sikkim namely, Bhaisa and Majulay, were detached, and distinguished by GC or GC-MS analytical protocols. Sixty ingredients representing about $94.9 \%$ and $92.6 \%$ of the Bhaisa and Majulay oils were recognized. The significant ingredients of Bhaisa oil were geranyl acetate $(18.8 \%)$ then zingiberene $(16.3 \%)$ and finally geranial $(8.2 \%)$ and those of Majulay oil were zingiberene $(19.8 \%)$ then geranial $(16.5 \%)$. Compared to various ginger cultivar oils, the Bhaisa oil possessed senior constituents of oxygenated ingredients (43.1\%). 


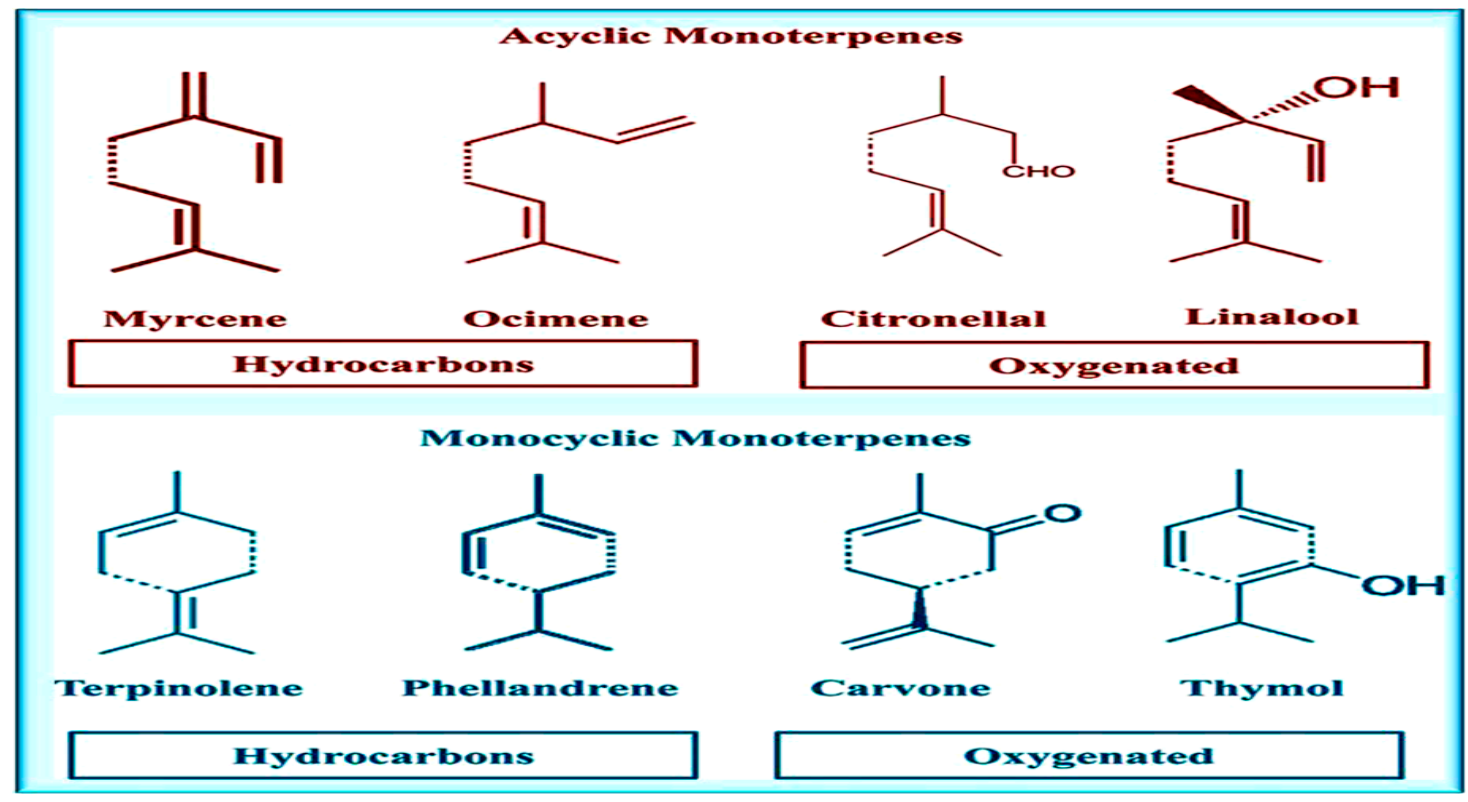

Figure 1. Structure of some monoterpenes.

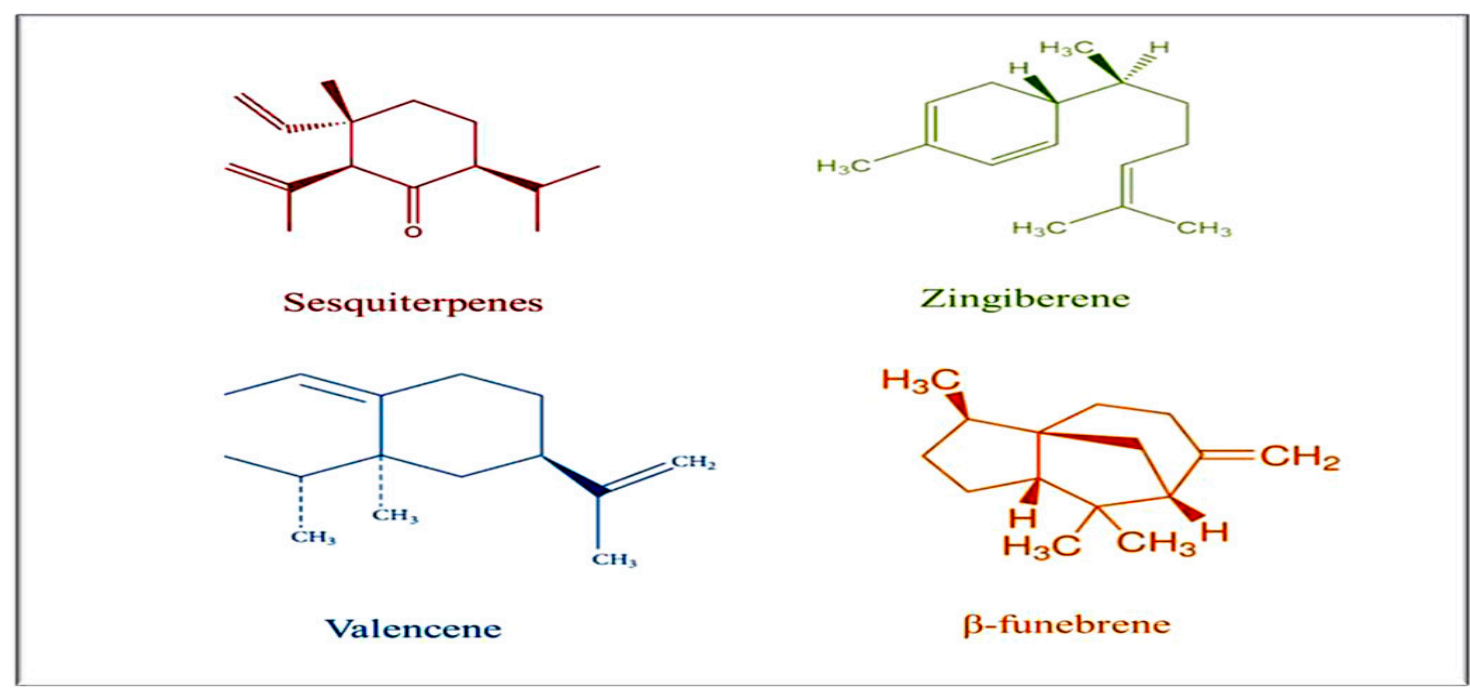

Figure 2. The major sesquiterpene components.

Bhattarai et al. [31] aimed to establish the chemical constituents of necessary oil and biological assays from the crude ethanolic extract of ginger from Sindhupalchhowk, Tanahu and Gorkha region of Nepal. Ginger essential oils were extracted using hydro distillation, and having the yield percent; Gorkha: 1.9, Sindhupalchowk: 1.8 and Tanahu: 1.1. GC-MS technique showed the existence of 105, 85 and 88 ingredients from Sindhupalchowk, Tanahu and Gorkha ginger respectively, with the major constituntes, monoterpenes and sesquiterpenes derivatives. The Soxhlet extraction was performed for the $95 \%$ ethanolic extraction from fresh ginger (EE) and the residue ginger after essential oil extraction.

Stoyanova et al. [32] studied the chemical ingredients of basic oils extracted either by steam distillation or water of ginger collected from Vietnam. The obtained basic oils were 2.05\% and $2.1 \%$, respectfully. The critical ingredients of the basic oil extracted by aqueous distillation protocol were curcumene $(11.7 \%)$ then $\beta$-bisabolene $(4.1 \%)$, and of the basic oil extracted by vapour distillation technique were curcumene (12.6\%) then $\alpha$-zingiberene $(10.3 \%), \beta$-bisabolene $(8.1 \%)$ and $\beta$-sesquiphellandrene (7.4\%). 
El-Baroty et al. [33] demonstrated that basic oils extracted from the roots of Zingiber officinale were distinguished by TLC or GC-MS analytical protocols, and both their antioxidant and antimicrobial ingredients were mentioned by TLC supported bioautography techniques. Ginger oil was differentiated by great constituent of sesquiterpene hydrocarbons, including $\beta$-sesquiphellandrene (27.16\%) then caryophyllene (15.29\%), zingiberene $(13.97 \%), \alpha$-farnesene $(10.52 \%)$ and curcumene $(6.62 \%)$. Chemical structure of important phytochemicals present in ginger is presented in Figure 3.

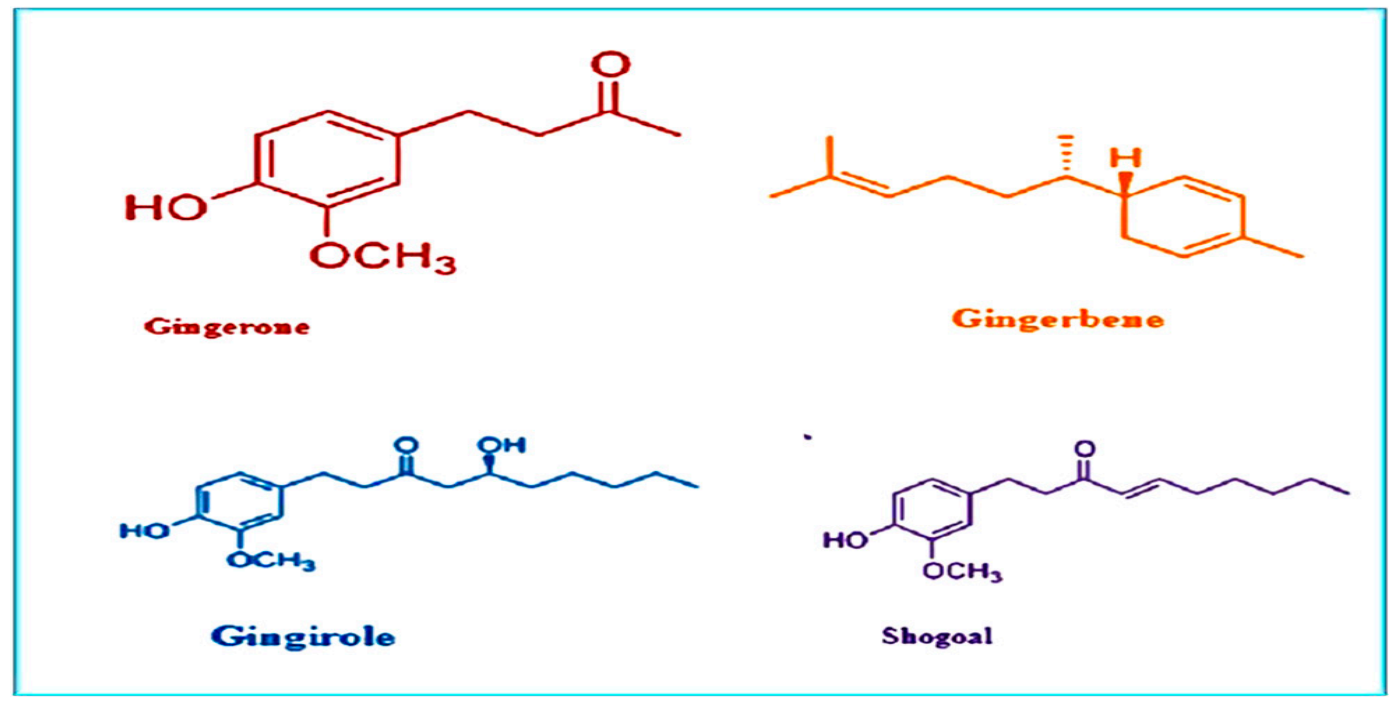

Figure 3. Chemical structure of important phytochemicals present in ginger.

\section{Beneficial Application of Ginger and Its Derivatives in Poultry Nutrition}

Beneficial effects of ginger and its derivatives in poultry nutrition are illustrated in Table 1 and Figure 4.

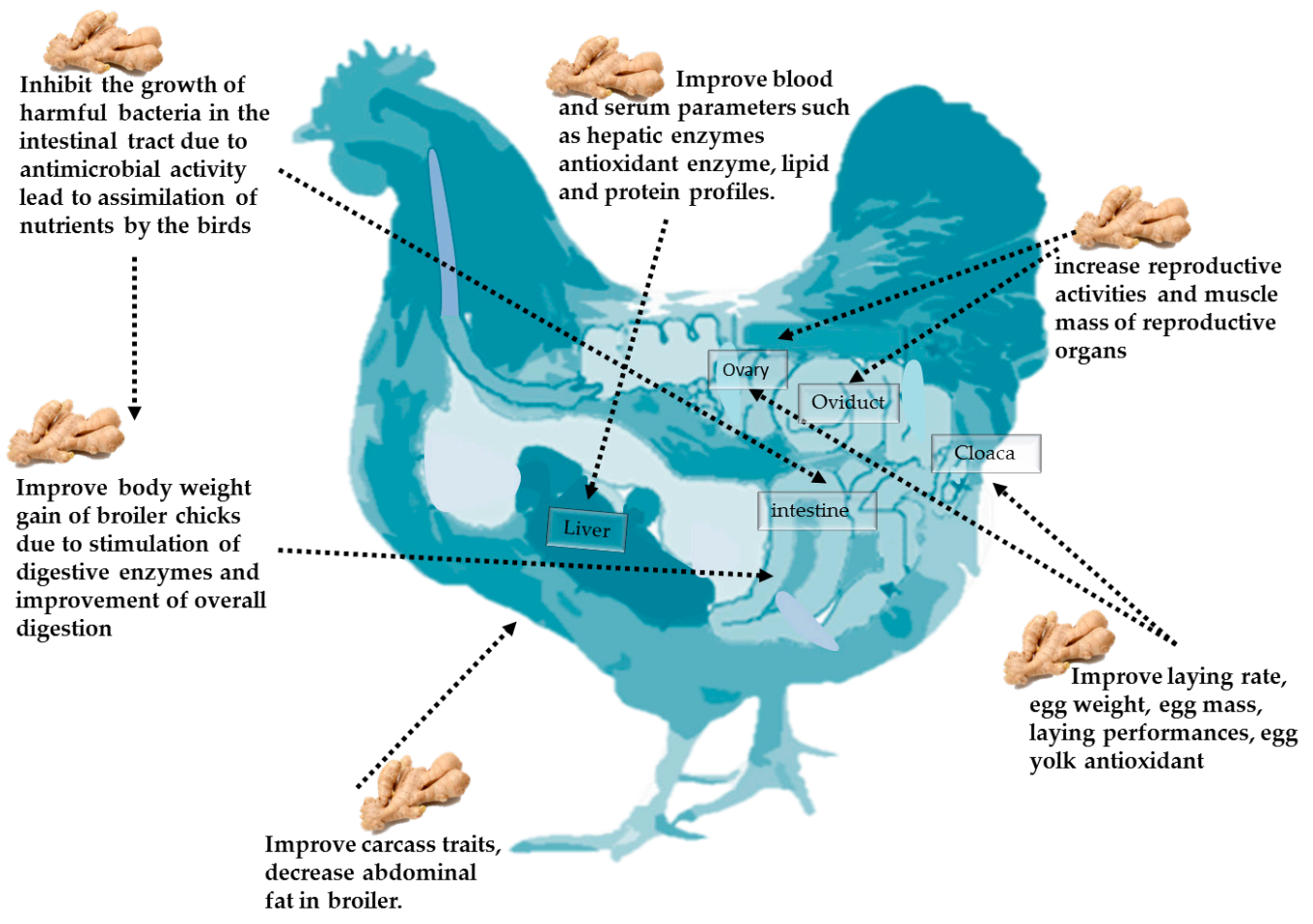

Figure 4. The beneficial application of ginger and its derivatives in poultry nutrition. 


\subsection{Effects of Ginger on Body Weight}

Dieumou et al. [34] found that the study extended for at least seven weeks without variations in feed conversion ratio (FCR) and body weight (BW) profits among the birds feed (control) or $10 \mathrm{mg} / \mathrm{kg} /$ day (ginger oil). Shanoon et al. [35] performed a study to assess the impact of ginger oil on the microbial population and growth performance of broilers. Two hundred of both females and males, one-day-old chicks of Ross 308 were allocated in a perfect incidental form trial, into four treatments grouping for seven weeks; doses 0 (Control), $10 \mathrm{mg} / \mathrm{kg} / \mathrm{day}, 20 \mathrm{mg} / \mathrm{kg} /$ day and $40 \mathrm{mg} / \mathrm{kg} / \mathrm{day}$. This study showed no clear variations in feed intake, FCR and BWG among the treated birds. Herve et al. [36] evaluated four different diets that contained $\left(100 \mu \mathrm{l} / \mathrm{kg}\right.$ BW of clean $\mathrm{H}_{2} \mathrm{O}$ as control, 50, 100, and $150 \mu \mathrm{l} / \mathrm{kg}$ $\mathrm{BW}$ of ginger basic oil sequentially). This research was conducted to assess the outcomes of ginger (Zingiber officinale) basic oil on growth parameters and biochemical oxidative/antioxidant features. Also, the histological configuration of testes and subsequently fertility features in Japanese quail. The main data mentioned that growth features were not clearly changed by essential oil regardless of dosage. The weight of left testis clearly elevated in basic oil treatments (100 or $150 \mu \mathrm{l} / \mathrm{kg}$ BW) when compared with the other groups.

Herve et al. [37] discovered the impacts of ginger (Zingiber officinale) basic oil on laying and growth features, beside cholesterol level and egg yolk antioxidant in Japanese quail. Eighty birds were randomly and equally allocated into four experimental groups treating orally and daily, $100 \mu \mathrm{l} / \mathrm{kg}$ BW clean $\mathrm{H}_{2} \mathrm{O}$ and 50,100, and $150 \mu \mathrm{l} / \mathrm{kg}$ BW of ginger roots extracted basic oil. Outcomes exposed that FCR and body weight gain (BWG), were not clearly mentioned by oral administration of ginger rhizomes extracted basic oil. The oral application of ginger rhizomes extracted basic oil had no obvious outcomes on gizzard, heart, intestine and liver weights when put in comparison with the control data. Weight of eggs clearly improved in Japanese quails orally administered with ginger roots extracted basic oil no matter what the dose level with special attention to the control data.

Habibi et al. [38] evaluated the outcomes of ginger addition on growth, antioxidant and carcass features as well as blood profile in broiler chicks exposed to heat stress environment $\left(32 \pm 2{ }^{\circ} \mathrm{C}\right.$ for 8 hour each day). Male broiler chicks were equally and haphazardly allocated into 6 dietary treated groups. A basic diet with no add-on, basic diet coupled with vitamin $\mathrm{E}(100 \mathrm{mg} / \mathrm{kg})$, basic diet plus either 7.5 or $15 \mathrm{~g} / \mathrm{kg}$ of ginger root powder, and feeds enclosing 75 or $150 \mathrm{mg} / \mathrm{kg}$ BW of ginger basic oil. There were no clear changes among the treated groups concerning BW profits, feed intake features and FCR after 42 and 49 days of age.

Mohamed [39] evaluated the growth parameters outcomes of broiler chicks nourished on graduated levels of garlic and ginger essential oils mixture during 42 days. Unsexed Arbor Acres (84 birds, 7days-old) were haphazardly and equally allocated into four experimental categories. The first group was fed a basic diet without feed add-on, the other treated groups were fed basic feeds mixed with different combinations of garlic and ginger essential oils at levels of (100 g ginger $+100 \mathrm{~g}$ garlic)/ton, $(200 \mathrm{~g}$ ginger $+200 \mathrm{~g}$ garlic)/ton and (300 g ginger $+300 \mathrm{~g}$ garlic)/ton. The data revealed that there were no clear variations of BWG and FCR among all treated groups.

Abd El-khalek and ELnaggar, [40] investigated the impact of ginger oil (Zingiber officinale Roscoe), black seed oil (Nigella sativa L.), thyme oil (Thymus vulgaris L.) and oregano oil (Origanum vulgare L.) as medicinal plants on the productive performance, blood constituents and DNA concentration of Gimmizah chicks. A total of 405 unsexed Gimmizah chicks (4 weeks of age) were randomly assigned to nine treatment categories of three simulates each. All chicks were raised in battery brooder placed in a temperature-controlled room until 16 weeks of age. Chicks in treatments 1, 2, 3 and 4 were fed a basic diet combined with $1 \mathrm{ml}$ of ginger, black seed, thyme or oregano/kg diet, respectively. Chicks of treatments 5, 6, 7 and 8 were fed a basal diet with the addition of $0.5,1.0,1.5$ and $2.0 \mathrm{ml} / \mathrm{kg}$ diet of an equal mixture of the previous medicinal plants together, respectively. Treatment 9 was used as a control. Results indicated that, the highest BW attain were recorded for the birds fed a basal diet with the addition of $1 \mathrm{ml}$ oregano/kg diet. Also, Ghasemi and Taherpour [41] distinguished the outcomes of the basal diet including ginger essential oil (50,100 or $200 \mathrm{mg} / \mathrm{kg}$ diet) plus mannan-oligosaccharide (2 g/kg 
diet) on growth features. One-day-old male broiler chicks (375 chicks) were haphazardly and equally assigned into five categories. Data revealed that the birds nourished on mannan-oligosaccharide plus ginger essential oil (200 $\mathrm{mg} / \mathrm{kg}$ diet) mixture showed an improved BWG from the first to 42 days of age when compared with control data.

Tekeli et al. [42] utilized 105, one-day-old male broiler chicks (Ross 308) to compare different diets as growth promoter agents for 42 days. The chicks were randomly and equally allocated into seven dietary treatment groups (basic diet), (basic diet $+10 \mathrm{mg}$ flavomycin $/ \mathrm{kg}$ diet), (basic diet $+120 \mathrm{mg}$ Yucca schidigera extract $/ \mathrm{kg}$ diet), (basic diet $+120 \mathrm{mg}$ Oreganum vulgare essential oil $/ \mathrm{kg}$ diet), (basic diet $+120 \mathrm{mg}$ Thymus vulgaris basic oil $/ \mathrm{kg}$ diet), (basic diet $+120 \mathrm{mg}$ Syzygium aromaticum basic oil $/ \mathrm{kg}$ diet) and (basic diet $+120 \mathrm{mg}$ Zingiber officinale essential oil $/ \mathrm{kg}$ diet). Data revealed that $Z$. officinale advanced the BWG in comparison with other treated groups.

\subsection{Effect of Ginger and Its Derivatives on Carcass Traits}

Tekeli et al. [42] mentioned that the dietary supplement of herb extracts, (Z. officinale) stimulated growth feature and the population of beneficial microorganisms. Dietary supplement of O. vulgare or Z. officinale or S. aromaticum lowered the total measure of the digestive tracts of treated chickens, but advanced mass of jejunum. Also, it could be concluded that $Z$. officinale could replace antibacterials which have been prohibited to be used as growth promoting in animal nutrition. Herve et al. [36] confirmed that the liver weight was decreased in ginger basic oil-treated quails.

Dieumou et al. [34] revealed that the majority of organ mass and carcass features were not suffered during the treatments, but for a drop in corresponding to the liver mass of chickens on garlic oil exposure when put in comparison with those data were given by either control or ginger oil. On the same way, a drop in the ratio of the head mass of chickens were administered basic oils was noticed to the control data. Dosages could cause a drop in relative mass of organs except for the gizzard and head when put in comparison to the control data. Male broilers were described less advanced than the females.

The oral application of ginger roots extracted basic oil $(0,0.25 \%, 0.50 \%$ and $0.75 \%)$ had insignificant outcomes on gizzard, heart, liver, and intestine considerable mass when differentiated to the control data, but the abdominal fat mass was significantly dropped in all exposed quails [43]. Mohamed [39] mentioned that carcass dressing and dependent meat quality features were not affected by adding of garlic and ginger essential oils mixture in the broiler diet.

\subsection{Effect of Ginger and Its Derivatives on Egg Production and Quality}

Osman [43] studied the effect of adding ginger oil in the diet on egg production and egg quality of Japanese quail in all periods of the experiment. Birds in the 8 weeks of age were distributed randomly on the four treatments, including four levels of ginger oil $(0,0.25 \%, 0.50 \%$ and $0.75 \%)$. The egg production and the production cumulative egg rate did not record also significant differences in the first period, but in the subsequent results of the experiment mentioned that there was no clear variation in the rate of treatments between three periods observed there significant superiority has added its oil treatments ginger in comparison with control as significant superiority in egg mass appeared to all treatments during the four periods of the experiment. So appeared obvious change in albumin weight when the fourth period, despite not appear significant differences in the first three periods and high significant in shell weight in the second period, while no significant differences did not appear in other periods for this trait, as well as did not record a significant differences in high yolk, yolk diameter, weight yolk, yolk index, high albumin and shell thickness.in addition to this study concludes that all additions ginger oil in Japanese quail diet led to significant superiority in egg production, no significant differences in quality characteristics of the eggs. Egg mass clearly advanced in Japanese quails exposed to ginger roots extracted basic oil without concerning the level of the dose with special attention to the control data [43].

Ginger roots extracted basic oil could be utilized in poultry to minimize lipid peroxidation status in germinal tissues and so, advanced the fertility status. In addition, oral application of 100-150 $\mu \mathrm{l} / \mathrm{kg}$ BW of ginger roots extracted basic oil on laying Japanese quails, the highest outcomes on egg mass and 
lowered egg levels without any harmful factors on feed uptake and BW profits [36]. On the other hand, Herve et al. [37] noticed that egg productiveness features, and weekly weight of eggs were not clearly affected by oral application of ginger roots extracted basic oil. An et al. [44] investigated ginger extract on the productiveness, antioxidant and immunity features of laying hens. The control birds were fed the basic diet; the experimental birds were fedbasic diets plus $0.1 \%$ ginger extract. Ginger extract clearly advanced laying rates with daily egg weight.

\subsection{Effect of Ginger on Reproductive Performance}

Herve et al. [36] mentioned that the dose level of 100 and $150 \mu l$ ginger basic oil $/ \mathrm{kg}$ BW, this basic oil caused a clear advancement in fertility ratio in comparison to the control outcomes. On the other side, Tchoffo et al. [45] assessed the outcomes of ginger roots extracted basic oil on some generative features of laying birds, 80 female Japanese quails were haphazardly allocated into 4 dietary categories ( 3 weeks of age). From the 3rd till 13th week, Japanese quails in group one, orally treated by clean $\mathrm{H}_{2} \mathrm{O}(100 \mu \mathrm{l} / \mathrm{kg} \mathrm{BW})$, all over the same time, orally gavaged 50, 100 and $150 \mu \mathrm{l}$ of ginger roots basic oil per kg BW. No clear advances were noticed during the trial for body and individual ovary relative weights. While, the individual uteri mass clearly advanced in dose-associated pattern. In addition, fertility, hatchability, hatchability rate and chick's weight clearly advanced in poultry treated by 100 and $150 \mu \mathrm{l} / \mathrm{kg}$ BW in relation to those of control data. Embryonic deaths dropped clearly with any level of the ginger rhizomes essential oil dose [45].

\subsection{Effect of Ginger on Blood Parameters}

Dieumou et al. [34] evaluated that the impact of garlic and ginger basic oils on some blood parameters of broiler chickens. Forty unsexed two-days old chicks of Arbor acres were allocated in four experimental groups. They were received via stomach tube either four doses; 0 (Control), $10 \mathrm{mg} / \mathrm{kg} / \mathrm{day}, 20 \mathrm{mg} / \mathrm{kg} / \mathrm{day}$, and $40 \mathrm{mg} / \mathrm{kg} /$ day. The result showed no clear variations recorded in serum alanine transaminase (ALT) aspartate transaminases (AST) and serum creatinine features due to ginger treatments.

Shanoon et al. [35] theorized that there were no obvious differentiations in serum transaminases (AST or ALT) and blood creatinine features, indicating that none of the examined three dosages of the oil that were administered to birds was harmful. Also, Herve et al. [36] confirmed that the serum contents of transaminases, malondialdehyde (MDA), triglycerides and total cholesterol were decreased in treated quails. The serum features in total protein, globulin and antioxidant enzymes were elevated in exposed birds considered to the control data. As well, Herve et al. [37] found that the serum features of total cholesterol, low density lipoprotein (LDL), and transaminases (AST or ALT) clearly dropped with 100 or $150 \mu \mathrm{l} / \mathrm{kg}$ BW of ginger roots extracted basic oil when compared to control data, as reported by also found that the oral application of 100 or $150 \mu \mathrm{l} / \mathrm{kg}$ BW of ginger roots extracted essential oil to laying Japanese quails greatly dropped cholesterols (serum or egg) levels without any harmful outcomes on feed uptake and BW profits.

Saleh et al. [46] monitored the outcomes of feed supplements of either thyme or ginger basic oils on hematological, biochemical and immunological features of broilers. A 105 one-day-old Ross 208 broilers in seven experimental groups. The control group received only the basic feed. The experimental feeds considering thyme oil at doses of 100 (T100), 200 (T200) and 300 (T300) mg/kg BW. Ginger oil at doses of 100 (G100), 200 (G200) and 300 (G300) mg/kg BW. The hematological outcomes cleared an obvious elevation in packed cell volume or hemoglobin in T200 group and in total leukocytes count especially heterophils percentage in both T200 and G100 groups. Total protein or globulin clearly dropped in G200 or G300 groups. While, group G100 indicated the better impact on lipid parameters.

Habibi et al. [38] demonstrated that the category was received $150 \mathrm{mg} / \mathrm{kg}$ BW ginger extracted basic oil, caused the total SOD function in hepatic tissue was elevated in relation to the control data. MDA values in hepatic tissue were diminished in the groups fed either ginger powder or basic oil in relation to that in the control data. Insignificant variations among treated groups considering, total SOD, glutathione peroxidase (GSH-PX) and catalase enzymes in red blood cells were recorded. All treated 
groups showed elevations in total antioxidant capacity (TAOC) or lowered MDA contents in serum in relation to the control data. Besides, Shanoon et al. [35] revealed that there were insignificant variations noticed in the serum transaminases (AST or ALT) and serum creatinine values, improving that neither of the these three levels of oil (10, 20 and $40 \mathrm{mg} / \mathrm{kg}$ BW /day) that were administered to birds was toxic.

Abd El-khalek and ELnaggar [40] found that addition of different medicinal plants either alone or in a mixture at any level significantly decreased plasma total cholesterol concentration and the activity of ALT compared to control. Also, Tchoffo et al. [45] confirmed that the values of serum total proteins, estradiol, follicle stimulating hormone and luteinizing hormone were greatly improved in a dose-associated pattern.

Al-Tahtawy et al. [47] examined the outcomes of Zingiber officinale Roscoe (ginger) extraction on hypercholesterolemic atherosclerosis condition due to expected antioxidant capacity. Data revealed a clear depression in the features of cholesterol, phospholipids, triglycerides and (VLDL or LDL) cholesterol levels in both serum and aortic tissue homogenate associated with high doses of ginger extraction. In addition, the antioxidant action of ginger extraction was estimated through its radical scavenging action (RSA), using rapid 1,1-diphenyl-2- picrylhydrazyl (DPPH) technique, indicated maximum antioxidative action associated with high doses of ginger extract.

An et al. [44] mentioned that ginger extraction did not modify the action of GSH-PX and TAOC, but only modified plasma SOD feature, decreased MDA value of the birds. In addition, ginger extract did not modify the values of serum total protein, albumin, globulin, but positively magnified lysozyme (LZM) action. On the same line, ginger extract clearly lessened prostaglandin E2 (PGE2) value. Moreover, Ghasemi and Taherpour [41] recognized that serum cholesterol values were diminished in the ginger essential oils $(100 \mathrm{mg} / \mathrm{kg}$ ) and mannan-oligosaccharide-supplemented diet.

Tekeli et al. [42] presented that blood cholesterol values, on the other side, blood glucose values was advanced by $Z$. officinale, at the same time blood triglyceride values was elevated by both $Z$. officinale and $S$. aromaticum dietary treatments.

The serum AST, ALT, total cholesterol and LDL-cholesterol were markedly decreased with 100 or $150 \mu \mathrm{l} / \mathrm{kg}$ BW of ginger roots extracted basic oil when considered with control data [37]. Oral application of $100-150 \mu \mathrm{l} / \mathrm{kg}$ BW of ginger roots extracted basic oil on laying Japanese quails, lowered serum cholesterol levels without any harmful factors on feed uptake and BW profits [36].

\subsection{Effect of Ginger and Its Derivatives on Microbiological Aspects}

Dieumou et al. [34] evaluate that Escherichia coli, like majority of Enterobacteriaceae populations in the ileo-cæcal contents quantitatively diminished in comparison with the control data in response to increased levels of ginger essential oils. The same measures were performed for the Salmonella and Shigella species. Staphylococci spp CFU (colony forming units) were nearly identical between ginger oil-treated groups, but were clearly diminished in comparison to the control data. Yeast and molds were present in the ileo-cæcal contents of all experimental groups.

Sharma et al. [29] discovered that the ginger essential oil evidenced clear antimicrobial actions against selected bacterial (Staphylococcus aureus, Escherichia coli and Pseudomonas aeruginosa) and fungal (Aspergillus niger and Candida albicans) populations. Ginger basic oil primarily included large characters of monoterpenes as sesquiterpenes, and showed critical antimicrobial action against most pathogenic microorganisms.

Bhattarai et al. [31] discussed the antimicrobial action of $8 \%$ ginger extraction from fresh ginger and the residue ginger after essential oil extraction against selected bacterial populations (Staphylococcus aureus, Klebsiella spp and Escherichia coli) stated through the inhibition zone and compared with chloramphenicol data. Similarly, the antioxidant capacity was executed by DPPH radical scavenging technique in a wide variety of concentrations. Since, fresh ginger or the residue ginger after essential oil extraction displayed the maximum percentage inhibition as compared with ascorbic acid, but the essential oil did not have the antioxidant actions. 
Norajit et al. [48] mentioned that ginger essential oil extracted by hydrodistillation possessed a maximum capacity towards three gram-positive bacterial strains, with a minimal concentration to suppress both L. monocytogenes and B. cereus of $6.25 \mathrm{mg} / \mathrm{mL}$. Stoyanova et al. [32] evaluated the antimicrobial action of basic oils extracted from ginger herb by agar diffusion technique. The examined microorganisms were some gram-positive strains (Bacillus subtilis, Bacillus pumilus, Staphylococcus aureus and Staphylococcus epidermidis); some gram-negative strains (Salmonella abony, Escherichia coli and Pseudomonas aeruginosa); some yeast strains (Candida albicans and Saccharomyces cerevisiae) and some fungal strains (Aspergillus niger, Botrytis cinerea, Penicillium spp. and Rhizopus nigricans). The basic oil exhibited a little action over the examined gram-positive and gram-negative strains and possessed a potential fungicidal action on the examined fungal strains. Abd El-khalek and ELnaggar [40] suggested that the intestinal total anaerobic and aerobic bacterial counts as well as the counts of coliforms population minimized due to the addition of various medicinal herbs combined or singly whatever the concentration level comparable to control data.

Majolo et al. [49] quantified components and examined the antibacterial action of basic oils originated from roots of Zingiber officinale Roscoe or Curcuma longa L. The extraction techniques of basic oils were executed by recommended GC-MS option. The antibacterial action was executed with microdilution broth technique. The essential oil of ginger was clearly approved to be more effective than turmeric oil, both were considered of bacteriostatic impact (minimum inhibitory concentration $2500-5000 \mu \mathrm{g} / \mathrm{mL}$ ) or bactericidal impact (minimum bactericidal concentration 5000-10000 $\mu \mathrm{g} / \mathrm{mL}$ ). So, ginger essential oil was considered as a substitute agent for governing of Salmonella enterica infection.

Tekeli et al. [42] concluded that dietary addition of Z. officinale improved beneficial bacteria population, like lactic acid bacterial population in the small intestine mainly jejunum. El-Baroty et al. [33] reported that ginger-extracted oil could show a significant suppressing action against some picked bacterial strains and some pathogenic fungi, with recorded minimum inhibitory concentration (MIC) levels extending from 20 to $120 \mu \mathrm{g} / \mathrm{mL}$ according to the bacterial strains. By increasing doses of oil, Escherichia coli or other Enterobacteria (Salmonella and Shigella) populations in the intestinal contents significantly dropped when compared with control data [35].

Table 1. Beneficial effects of ginger and its derivatives in poultry nutrition.

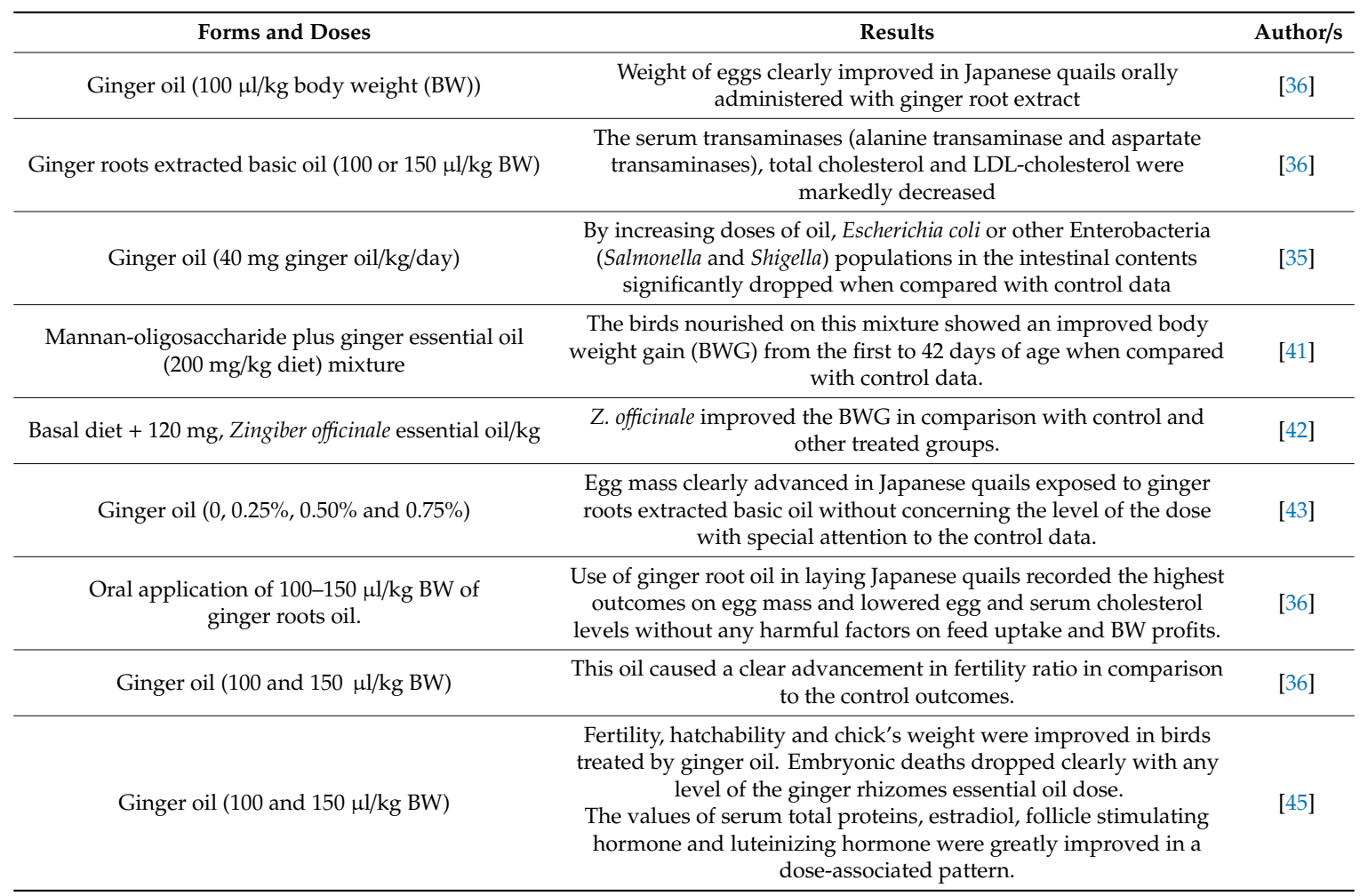


Table 1. Cont.

\begin{tabular}{|c|c|c|}
\hline Forms and Doses & Results & Author/s \\
\hline $0.1 \%$ ginger extract & Ginger extract clearly advanced laying rates with daily egg weight & [44] \\
\hline Ginger oil (100 and 150 1/kg BW) & $\begin{array}{l}\text { Serum contents of malondialdehyde (MDA), triglycerides and total } \\
\text { cholesterol serum features were decreased. Total protein, globulin } \\
\text { and antioxidant enzymes were elevated. }\end{array}$ & [36] \\
\hline Ginger oil at doses of 100, 200 and $300 \mathrm{mg} / \mathrm{kg}$ BW. & Ginger oil at dose of $100 \mathrm{mg} / \mathrm{kg}$ BW improved serum lipid profile. & [46] \\
\hline Ginger extraction & Ginger extract clearly lessened prostaglandin E2 (PGE2) value. & [44] \\
\hline Ginger essential oils (100 mg/kg) & $\begin{array}{l}\text { Serum cholesterol values were diminished in the ginger essential oil } \\
\text { and mannan-oligosaccharide supplemented diet. }\end{array}$ & [41] \\
\hline Z. officinale & $\begin{array}{l}\text { Blood glucose values were advanced by Z. officinale, at the same } \\
\text { time blood triglyceride values was elevated by both Z. officinale and } \\
\text { S. aromaticum dietary treatments. }\end{array}$ & [42] \\
\hline Ginger essential oil & $\begin{array}{c}\text { Staphylococcus aureus, Bacillus subtilis, Escherichia coli and } \\
\text { Pseudomonas aeruginosa and fungal (Aspergillus niger and Candida } \\
\text { albicans) populations were decreased with ginger } \\
\text { oil supplementation. }\end{array}$ & [29] \\
\hline $\begin{array}{l}8 \% \text { ginger extraction from fresh ginger and the } \\
\text { residue ginger after essential oil extraction. }\end{array}$ & $\begin{array}{l}\text { Staphylococcus aureus, Bacillus subtilis, Klebsiella spp and Escherichia } \\
\text { coli were decreased with ginger oil supplementation. }\end{array}$ & {$[31,49]$} \\
\hline Ginger extracted oil & $\begin{array}{l}\text { Ginger extracted oil could show a significant suppressing action } \\
\text { against some picked bacterial strains. }\end{array}$ & [33] \\
\hline Ginger oil for 30 days & $\begin{array}{l}\text { Oral application of ginger oil for at least } 30 \text { days, critically improved } \\
\text { glutathione reductase, glutathione and SOD values. }\end{array}$ & [26] \\
\hline Ginger essential oil (125 ppm) & $\begin{array}{l}\text { In broiler chickens receiving ginger essential oil greater high density } \\
\text { lipoprotein (HDL) and lower VLDL levels, whereas no significant } \\
\text { difference was observed in LDL concentration. Ammonia } \\
\text { concentration in ileum was the lowest in broiler fed with essential } \\
\text { oil supplementation. }\end{array}$ & [52] \\
\hline Ginger extract & $\begin{array}{l}\text { Ginger extract enhances the serological response and had an } \\
\text { antioxidant activity (both in vitro and in vivo) mainly attributed to } \\
\text { pungent active principles like shogaols and gingerols. }\end{array}$ & [22] \\
\hline Ginger rhizome (10 mg/kg) & $\begin{array}{c}\text { In vitro, ginger extract showed antibacterial activity against } \\
\text { Salmonella typhimurium, Pseudomonas aeruginosa, Candida } \\
\text { albicans and Escherichia coli. }\end{array}$ & [53] \\
\hline $\begin{array}{l}\text { Basal diet plus } 2 \mathrm{~g} / \mathrm{kg}, 4 \mathrm{~g} / \mathrm{kg} \text { and } 6 \mathrm{~g} / \mathrm{kg} \\
\text { ginger powder }\end{array}$ & $\begin{array}{l}\text { Ginger powder increased hemagglutination inhibition (HI) titre } \\
\text { against Newcastle Disease virus. Also, ginger powder at } 6 \mathrm{~g} / \mathrm{kg} \\
\text { increased the leucocytes count and serum total protein, but } \\
\text { decreased cholesterol and high-density lipoprotein (HDL) levels. }\end{array}$ & [54] \\
\hline Aqueous extracts of ginger & $\begin{array}{l}\text { Aqueous extract of ginger improved performance and plays an } \\
\text { immune stimulant against Newcastle Disease. }\end{array}$ & [55] \\
\hline $0.1 \%$ and $0.2 \%$ ginger & Birds fed $0.1 \%$ and $0.2 \%$ ginger had better feed conversion ratio & {$[56]$} \\
\hline $\begin{array}{l}\text { Ginger powder }(5,10,15, \text { or } 20 \mathrm{~g} / \mathrm{kg} \text { of diet }) \\
\text { for } 10 \text { weeks. }\end{array}$ & $\begin{array}{l}\text { Dietary supplementation of ginger powder at } 15 \text { or } 20 \mathrm{~g} / \mathrm{kg} \\
\text { enhanced performance and egg yolk and serum antioxidant status } \\
\text { and improved dietary oxidation stability in a dose-dependent } \\
\text { manner in laying hens. }\end{array}$ & [57] \\
\hline
\end{tabular}

\subsection{Effect of Ginger on Meat and Egg Quality}

In previous literatures, the impacts of ginger or its derivatives on the meat quality and chemical composition of meat are rare. Ginger is an important source of the plant proteolytic enzyme. Naveena 
and Mendiratta [58] stated that the extracts of ginger have proteolytic activity, resulting in an increase in the solubility of collagen and proteolysis in this herb extract treated spent chicken muscle. On the other hand, Attia et al. [59] studied the effect of ginger on performance and cost of supplementation and they found that dietary supplementation of $0.5 \%$ ginger decreased meat lipids and plasma glucose in comparison with the control. Herawati and Marjuki [60] found that chickens given diets with ginger $(0.5,1.0,1.5$ and $2.0 \%)$ showed a significant decrease in the fat weight than birds given diet without ginger. Also, using ginger in broiler diets instead of chemical antibiotics slightly increased tenderness and $\mathrm{pH}$ of broiler meat, but decreased cooking loss and water holding capacity as compared to the control.

Ginger plays an important role in improving the egg quality, since, in Hyline Brown laying hens, dietary supplementation of ginger (100 g/ton for eight weeks) improved egg quality by increasing albumin height and Haugh unit of eggs than the control birds. Also, use of ginger in layer diets increased activity of T-SOD and decreased content of MDA and cholesterol in yolk than the control hens [61]. These results were consistent with the findings of Zhao et al. [57] who found that layer fed diets enriched with ginger powder decreased MDA concentration and increased T-SOD activity in egg yolk. Yang et al. [62] also stated that improved Haugh unit was accompanied by increased blood antioxidant enzymes in birds fed ginger root. This may be explained by the radical-scavenging effect of phenolic compounds and antioxidant components in ginger extract, which reduce lipid oxidation [63] and enhance the function of body organs as partly reflected by decreased the serum activities of ALT and AST, thus improving the production and synthesis of antioxidant enzymes [64]. On the same line, Gurbuz and Salih [65] found that powder of ginger root lowered yolk cholesterol content. The hypocholesterolemic effect of this plant was also recorded in broiler chickens [18]. Furthermore, the decrease in yolk content of cholesterol may be returned to the alterations of HDL-metabolism, which is involved in reverse the transport of cholesterol. Ginger extract may have used as a feed additive for increasing the production of low-cholesterol eggs, which would be preferred by consumers and customers because cholesterol is an indicator for cardiovascular diseases [66].

\subsection{Effect of Ginger on Economic Efficiency}

Ginger powder also could be utilized in poultry to minimize cost-benefit ratio and improve economic feasibility. Oleforuh-Okoleh et al. [67] studied the effect of ground ginger on the growth performance, carcass quality and economics of production of broiler chickens. They found ground ginger in water-based infusion at $50 \mathrm{~mL} /$ liter of drinking water or ground ginger at $14 \mathrm{~g} / \mathrm{kg}$ of the diet achieved the highest revenue and net return, and also gave the least cost-benefit ratio in comparison with the control [67]. Karangiya et al. [68] studied the effect of ginger, garlic and their combination on growth performance and economics in broilers. The income from selling of the birds was higher in $1 \%$ of ginger group than the control. During the whole experimental period, feed cost was higher in $1 \%$ of ginger group and $1+1$ ginger and garlic group than the control. Return over feed cost was lower $1 \%$ of ginger group and 1+1 ginger and garlic group than the control. It could be concluded that ginger did not show any positive or negative impact on Return over feed cost. Also, this study was in accordance with Mohammed and Yusuf [69] who observed no differences in cost of feed per kg BWG for broiler chickens due to dietary supplementation of ginger.

\section{Conclusions}

Ginger and its derivatives could be mentioned harmless due to possessing no acute toxicological collateral outcomes as reviewed through the experimental time. According to many studies, data were mentioned that the experimental feed supplements minimized gizzard mass and abdominal fat, but without outcomes in broiler growth features and carcass profiles. It can be also stated that feed supplements with ginger exhibited a positive domination upon immune action and antioxidants of broilers. It could be due to ginger possessed intense antioxidant action, considering that microbial based dietary add-on enhanced regular antibodies formation. A variety of alternatives have been 
utilized as antibacterial agents in the poultry manufacturing. Use of ginger extract as a feed additive to increase the production of low-cholesterol eggs, which would be preferred by consumers and customers because cholesterol is an indicator for cardiovascular diseases. Many research results indicated that ginger and its derivatives showed similar effects to antibiotics in poultry. In addition, appropriate doses and the method of application for these alternatives to antibiotics are important in order for them to be more effective in poultry.

Author Contributions: All the authors were equally contributed to the conception, design, analysis and interpretation of data. All authors have read and agreed to the published version of the manuscript, and agree to be accountable for its contents.

Acknowledgments: This research was funded by the Deanship of Scientific Research at the Princess Nourah bint Abdulrahman University through the Fast-track Research Funding Program.

Conflicts of Interest: The authors declare no conflicts of interest.

\section{References}

1. Abd El-Hack, M.E.; Mahgoub, S.A.; Alagawany, M.; Dhama, K. Influences of dietary supplementation of antimicrobial cold pressed oils mixture on growth performance and intestinal microflora of growing Japanese quails. Int. J. Pharmacol. 2015, 11, 689-696.

2. Abd El-Hack, M.E.; Mahgoub, S.A.; Hussein, M.M.; Saadeldin, I.M. Improving growth performance and health status of meat-type quail by supplementing the diet with black cumin cold-pressed oil as a natural alternative for antibiotics. Environ. Sci. Pollut. Res. Int. 2018, 25, 1157-1167. [CrossRef] [PubMed]

3. Hussein, M.M.; Abd El-Hack, M.E.; Mahgoub, S.A.; Saadeldin, I.M.; Swelum, A.A. Effects of clove (Syzygium aromaticum) oil on quail growth, carcass traits, blood components, meat quality, and intestinal microbiota. Poult. Sci. 2018, 98, 319-329. [CrossRef] [PubMed]

4. Kishawy, A.T.; Amer, S.A.; Abd El-Hack, M.E.; Saadeldin, I.M.; Swelum, A.A. The impact of dietary linseed oil and pomegranate peel extract on broiler growth, carcass traits, serum lipid profile, and meat fatty acid, phenol, and flavonoid contents. Asian-Australas J. Anim. Sci. 2019, 32, 1161-1171. [CrossRef] [PubMed]

5. Mahgoub, S.A.M.; Abd El-Hack, M.E.; Saadeldin, I.M.; Hussein, M.A.; Swelum, A.A.; Alagawany, M. Impact of Rosmarinus officinalis cold-pressed oil on health, growth performance, intestinal bacterial populations, and immunocompetence of Japanese quail. Poult. Sci. 2019, 98, 2139-2149. [CrossRef] [PubMed]

6. Cervantes, H. Banning antibiotic growth promoters: Learning from the European experience. Poultry Int. 2006, 10-12.

7. Elgeddawy, S.A.; Shaheen, H.M.; El-Sayed, Y.S.; Abd Elaziz, M.; Darwish, A.; Samak, D.; Batiha, G.E.; Mady, R.A.; Bin-Jumah, M.; Allam, A.A.; et al. Effects of the dietary inclusion of a probiotic or prebiotic on florfenicol pharmacokinetic profile in broiler chicken. J. Anim. Physiol. Anim. Nutr. 2020, 1-9. [CrossRef]

8. Mohamed, L.A.; El-Hindawy, M.M.; Alagawany, M.; Salah, A.S.; El-Sayed, S.A. Effect of low- or high-CP diet with cold-pressed oil supplementation on growth, immunity and antioxidant indices of growing quail. J. Anim. Physiol. Anim. Nutr. 2019, 103, 1380-1387. [CrossRef]

9. Reda, F.M.; Alagawany, M.; Mahmoud, H.K.; Mahgoub, S.A.; Elnesr, S.S. Use of red pepper oil in quail diets and its effect on performance, carcass measurements, intestinal microbiota, antioxidant indices, immunity and blood constituents. Animal 2019, 1-9. [CrossRef]

10. Alagawany, M.; Elnesr, S.S.; Farag, M.R. The role of exogenous enzymes in promoting growth and improving nutrient digestibility in poultry. Iranian J. Vet. Res. 2018, 19, 157-164.

11. Abd El-Hack, M.; Alagawany, M.; Farag, M.; Tiwari, R.; Karthik, K.; Dhama, K.; Zorriehzahra, J.; Milad, A. Beneficial impacts of thymol essential oil on health and production of animals, fish and poultry: A review. J. Essent. Oil Res. 2016, 28, 365-382. [CrossRef]

12. Abd El-Hack, M.E.; Abdelnour, S.A.; Taha, A.E.; Khafaga, A.F.; Arif, M.; Ayasan, T.; Abdel-Daim, M.M. Herbs as thermoregulatory agents in poultry: An overview. Sci. Total Environ. 2019, 134399. [CrossRef] [PubMed]

13. Alagawany, M.; Abd El-Hack, M.E.; Farag, M.R.; Sachan, S.; Karthik, K.; Khama, K. The use of probiotics as eco-friendly alternatives for antibiotics in poultry nutrition. Environ. Sci. Pollut. Res. 2018, 25, 10611-10618. [CrossRef] [PubMed] 
14. Alagawany, M.; Elnesr, S.S.; Farag, M.R.; Abd El-Hack, M.E.; Khafaga, A.F.; Taha, A.E.; Tiwari, R.; Yatoo, M.I.; Bhatt, P.; Marappan, G.; et al. Licorice (Glycyrrhiza glabra) herb as an eco-friendly additive to promote poultry health-Current Knowledge and Prospects. Animals 2019, 9, 536. [CrossRef]

15. Gado, A.R.; Ellakany, H.F.; Elbestawy, A.R.; Abd El-Hack, M.E.; Khafaga, A.F.; Taha, A.E.; Mahgoub, S.A. Herbal medicine additives as powerful agents to control and prevent avian influenza virus in poultry-a review. Ann. Anim. Sci. 2019. [CrossRef]

16. Elnesr, S.S.; Ropy, A.; Abdel-Razik, A.H. Effect of dietary sodium butyrate supplementation on growth, blood biochemistry, haematology and histomorphometry of intestine and immune organs of Japanese quail. Animal 2019, 13, 1234-1244. [CrossRef]

17. Kothari, D.; Lee, W.D.; Niu, K.M.; Kim, S.K. The Genus Allium as Poultry Feed Additive: A Review. Animals 2019, 9, 1032. [CrossRef]

18. Zhang, G.F.; Yang, Z.B.; Wang, Y.; Yang, W.R.; Jiang, S.Z.; Gai, G.S. Effects of ginger root (Zingiber officinale) processed to different particle sizes on growth performance, antioxidant status, and serum metabolites of broiler chickens. Poult. Sci. 2009, 88, 2159-2166. [CrossRef]

19. Ali, B.H.; Blunden, G.; Tanira, M.O.; Nemmar, A. Some phytochemical, pharmacological and toxicological properties of ginger (Zingiber officinale Roscoe): A review of recent research. Food Chem. Toxicol. 2008, 46, 409-420. [CrossRef]

20. Onu, P. Evaluation of two herbal spices as feed additives for finisher broilers. Biotechnol. Anim. Husb. 2010, 26, 383-392. [CrossRef]

21. Wang, W.H.; Wang, Z.M. Studies of commonly used traditional medicine-ginger. Zhongguo Zhong Yao Za Zhi 2005, 30, 1569-1573. [PubMed]

22. Khan, R.; Naz, S.; Nikousefat, Z.; Tufarelli, V.; Javdani, M.; Qureshi, M.; Laudadio, V. Potential applications of ginger (Zingiber officinale) in poultry diets. World's Poult. Sci. J. 2012, 68, 245-252. [CrossRef]

23. Asghar, A.; Farooq, M.; Mian, M.; Khurshid, A. Economics of broiler production in Mardan division. J. Rural Dev. Adm. 2000, 32, 56-65.

24. An, K.; Zhao, D.; Wang, Z.; Wu, J.; Xu, Y.; Xiao, G. Comparison of different drying methods on Chinese ginger (Zingiber officinale Roscoe): Changes in volatiles, chemical profile, antioxidant properties, and microstructure. Food Chem. 2016, 197, 1292-1300. [CrossRef] [PubMed]

25. Mahboubi, M. Zingiber officinale Rosc. essential oil, a review on its composition and bioactivity. Clinical Phytoscience 2019, 5, 6. [CrossRef]

26. Jeena, K.; Liju, V.B.; Kuttan, R. Antioxidant, anti-inflammatory and antinociceptive activities of essential oil from ginger. Indian J. Physiol. Pharmacol. 2013, 57, 51-62. [PubMed]

27. Govindarajan, V. Ginger-Chemistry, Technology and Quality Evaluation: Part I-CRC Critical Reviews in Food Science and Nutrition. Quensland 1982, 17, 98.

28. Singh, G.; Maurya, S.; Catalan, C.; De Lampasona, M.P. Studies on essential oils, Part 42: Chemical, antifungal, antioxidant and sprout suppressant studies on ginger essential oil and its oleoresin. Flavour Fragr. J. 2005, 20, 1-6. [CrossRef]

29. Sharma, P.K.; Singh, V.; Ali, M. Chemical composition and antimicrobial activity of fresh rhizome essential oil of Zingiber officinale Roscoe. Pharmacogn. J. 2016, 8, 185-190. [CrossRef]

30. Sasidharan, I.; Venugopal, V.V.; Menon, A.N. Essential oil composition of two unique ginger (Zingiber officinale Roscoe) cultivars from Sikkim. Nat. Prod. Res. 2012, 26, 1759-1764. [CrossRef]

31. Bhattarai, K.; Pokharel, B.; Maharjan, S.; Adhikari, S. Chemical Constituents and Biological Activities of Ginger Rhizomes from Three Different Regions of Nepal. J. Nutri. Diet Probiotics. 2018, 1, 180005.

32. Stoyanova, A.; Konakchiev, A.; Damyanova, S.; Stoilova, I.; Suu, P.T. Composition and antimicrobial activity of ginger essential oil from Vietnam. J. Essent. Oil-Bear. Plants. 2006, 9, 93-98. [CrossRef]

33. El-Baroty, G.S.; El-Baky, H.A.; Farag, R.S.; Saleh, M.A. Characterization of antioxidant and antimicrobial compounds of cinnamon and ginger essential oils. Afr. J. Biochem. Res. 2010, 4, 167-174.

34. Dieumou, F.E.; Teguia, A.; Kuite, J.R.; Tamokou, J.D.; Fonge, B.N.; Dongmo, M.C. Effects of ginger (Z. officinale) and garlic (Allium sativum) essential oils on growth performance and gut microbial population of broiler chickens. Livestock Res. Rural Dev. 2009, 21, 23-32.

35. Shanoon, A.K.; Jassim, M.S.; Amin, Q.H.; Ezaddin, I.N. Effects of Ginger (Zingiber officinale) Oil on Growth Performance and Microbial Population of Broiler Ross 308. Inter. J. Poultry Sci. 2012, 11, 589-593. [CrossRef] 
36. Herve, T.; Raphaël, K.J.; Ferdinand, N.; Vitrice, L.; Tiwa, F.; Gaye, A.; Moyo, N. 2018 Growth performance, serum biochemical profile, oxidative status, and fertility traits in male Japanese quail fed on ginger (Zingiber officinale, roscoe) essential oil. Vet. Med. Inter. 2018, 2018, 7682060. [CrossRef]

37. Herve, T.; Raphaël, K.J.; Ferdinand, N.; Victor Herman, N.; Marvel, W.; Moyo, N.; Tiwa, F. Effects of Ginger (Zingiber officinale, Roscoe) Essential Oil on Growth and Laying Performances, Serum Metabolites, and Egg Yolk Antioxidant and Cholesterol Status in Laying Japanese Quail. J. Vet. Med. 2019, 2019, 7857504. [CrossRef]

38. Habibi, R.; Sadeghi, G.H.; Karimi, A. Effect of different concentrations of ginger root powder and its essential oil on growth performance, serum metabolites and antioxidant status in broiler chicks under heat stress. Br.Poultry Sci. 2014, 55, 228-237. [CrossRef]

39. Mohamed, N.E.S. Response of Broiler Chicks to Diets Containing Mixture Garlic and Ginger Essential Oils as Natural Growth Promoter. Ph.D. Thesis, Sudan University for Science and Technology, Khartoum, Sudan, 2015.

40. Abd El-khalek, E.; ELnaggar, A.S. Growth and physiological response of gimmizah chicks to dietary supplementation with ginger, black seeds, thyme and oregano oil as natural feed additives. Egypt. Poult. Sci. J. 2016, 36, 1163-1182.

41. Ghasemi, H.A.; Taherpour, K. Comparison of broiler performance, blood biochemistry, hematology and immune response when feed diets were supplemented with ginger essential oils or mannan-oligosaccharide. Iranian J. Vet. Med. 2015, 9, 195-205.

42. Tekeli, A.; Celik, L.; Kutlu, H.R.; Gorgulu, M. Effect of dietary supplemental plant extracts on performance, carcass characteristics, digestive system development, intestinal microflora and some blood parameters of broiler chicks. In Proceedings of the 12th European Poultry Conference, Verona, Italy, 10-14 September 2006; pp. 10-14.

43. Osman, A.; El-Araby, G.M.; Taha, H. Potential use as a bio-preservative from lupin protein hydrolysate generated by alcalase in food system. J. Appl. Biol. Biotechnol. 2016, 4, 076-081.

44. An, S.; Liu, G.; Guo, X.; An, Y.; Wang, R. Ginger extract enhances antioxidant ability and immunity of layers. Anim. Nutr. 2019, 5, 407-409. [CrossRef]

45. Tchoffo, H.; Ngoula, F.; Kana, J.R.; Kenfack, A.; Ngoumtsop, V.H.; Vemo, N.B. Effects of ginger (Zingiber officinale) rhizomes essential oil on some reproductive parameters in laying Japanese quail (Coturnix coturnix japonica). Adv. Reprod. Sci. 2017, 5, 64-74. [CrossRef]

46. Saleh, N.; Allam, T.; El-Latif, A.A.; Ghazy, E. The effects of dietary supplementation of different levels of thyme (Thymus vulgaris) and ginger (Zingiber officinale) essential oils on performance, hematological, biochemical and immunological parameters of broiler chickens. Global Vet. 2014, 12, 736-744.

47. Al-Tahtawy, R.H.M.; El-Bastawesy, A.M.; Monem, M.A.; Zekry, Z.K.; Al-Mehdar, H.A.; El-Merzabani, M.M. Antioxidant activity of the volatile oils of Zingiber officinale (ginger). Spatula DD 2011, 1, 1-8. [CrossRef]

48. Natta, L.; Orapin, K.; Krittika, N.; Pantip, B. Essential oil from five Zingiberaceae for anti food-borne bacteria. Inter. Food Res. J. 2008, 15, 337-346.

49. Majolo, C.; Nascimento, V.P.; Chagas, E.C.; Chaves, F.C.M. Antimicrobial activity of essential oil from Curcuma longa and Zingiber officinale rhizomes against enteric Salmonella isolated from chicken. Rev. bras. Plantas Med. 2014, 16, 505-512. [CrossRef]

50. Qorbanpour, M.; Fahim, T.; Javandel, F.; Nosrati, M.; Paz, E.; Seidavi, A.; Ragni, M.; Laudadio, V.; Tufarelli, V. Effect of Dietary Ginger (Zingiber officinale Roscoe) and Multi-Strain Probiotic on Growth and Carcass Traits, Blood Biochemistry, Immune Responses and Intestinal Microflora in Broiler Chickens. Animals 2018, 8, 117. [CrossRef]

51. Alizadeh-Navaei, R.; Roozbeh, F.; Saravi, M.; Pouramir, M.; Jalali, F.; Moghadamnia, A.A. Investigation of the effect of ginger on the lipid levels. A double blind controlled clinical trial. Saudi Med. J. 2008, 29, 1280-1284.

52. Hong, J.C.; Steiner, T.; Aufy, A.; Lien, T.F. Effects of supplemental essential oil on growth performance, lipid metabolites and immunity, intestinal characteristics, microbiota and carcass traits in broilers. Livest. Sci. 2012, 144, 253-262. [CrossRef]

53. Jagetia, G.C.; Baliga, M.S.; Venkatesh, P.; Ulloor, J.N. Influence of ginger rhizome (Zingiber officinale Rosc) on survival, glutathione and lipid peroxidation in mice after whole-body exposure to gamma radiation. Radiat. Res. 2003, 160, 584-592. [CrossRef] 
54. Shewita, R.S.; Taha, A.E. Influence of dietary supplementation of ginger powder at different levels on growth performance, haematological profiles, slaughter traits and gut morphometry of broiler chickens. South Afr. J. Anim. Sci. 2018, 48, 997-1008. [CrossRef]

55. Azhir, D.; Zakeri, A.; Rezapour, A.K. Effect of ginger powder rhizome on humeral immunity of broiler chickens. Eur. J. Exp. Biol. 2012, 2, 2090-2092.

56. Arkan, B.M.; Mohammed, A.M.; Ali, J. Effect of ginger (Zingiber officinale) on performance and blood serum parameters of broilers. Int. J. Poult. Sci. 2012, 91, 143-146.

57. Zhao, X.; Yang, Z.B.; Yang, W.R.; Wang, Y.; Jiang, S.Z.; Zhang, G.G. Effects of ginger root (Zingiber officinale) on laying performance and antioxidant status of laying hens and on dietary oxidation stability. Poult. Sci. 2011, 90, 1720-1727. [CrossRef]

58. Naveena, B.M.; Mendiratta, S.K. Tenderisation of spent hen meat using ginger extract. Br. Poult. Sci. 2001, 42, 344-349. [CrossRef]

59. Attia, Y.A.; Saber, S.H.; Abd-El-Hamid, E.A.; Radwan, M.W. Response of broiler chickens to dietary supplementation of ginger (Zingiber officinale) continuously or intermittently in comparison with prebiotics. Egypt. Poult. Sci. 2017, 37, 523-543.

60. Herawati; Marjuki. The effect of feeding red ginger (Zingiber officinale Rosc.) as phytobiotic on broiler slaughter weight and meat quality. Inter. J. Poult. Sci. 2011, 10, 983-985. [CrossRef]

61. Wen, C.; Gu, Y.; Tao, Z.; Cheng, Z.; Wang, T.; Zhou, Y. Effects of Ginger Extract on Laying Performance, Egg Quality, and Antioxidant Status of Laying Hens. Animals 2019, 9, 857. [CrossRef]

62. Yang, C.W.; Ding, X.; Zhao, X.; Guo, Y.X.; Mu, A.L.; Yang, Z.B. Effects of star anise (Illicium verum Hook. f.), salvia miltiorrhiza (Salvia miltiorrhiza Bge) and ginger root (Zingiber officinale Roscoe) on laying performance, antioxidant status and egg quality of laying hens. Europ. Poult. Sci. 2017, 81. [CrossRef]

63. Si, W.; Chen, Y.P.; Zhang, J.; Chen, Z.Y.; Chung, H.Y. Antioxidant activities of ginger extract and its constituents toward lipids. Food Chem. 2018, 239, 1117-1125. [CrossRef]

64. Li, J.; Wang, S.; Yao, L.; Ma, P.; Chen, Z.; Han, T.L.; Yuan, C.; Zhang, J.; Jiang, L.; Liu, L.; et al. 6-gingerol ameliorates age-related hepatic steatosis: Association with regulating lipogenesis, fatty acid oxidation, oxidative stress and mitochondrial dysfunction. Toxicol. Appl. Pharmacol. 2019, 362, 125-135. [CrossRef]

65. Gurbuz, Y.; Salih, Y.G. Influence of sumac (Rhus Coriaria L.) and ginger (Zingiber officinale) on egg yolk fatty acid, cholesterol and blood parameters in laying hens. J. Anim. Physiol. Anim. Nutr. 2017, 101, 1316-1323. [CrossRef]

66. Abdollahi, A.M.; Virtanen, H.E.K.; Voutilainen, S.; Kurl, S.; Tuomainen, T.P.; Salonen, J.T.; Virtanen, J.K. Egg consumption, cholesterol intake, and risk of incident stroke in men: The Kuopio Ischaemic Heart Disease Risk Factor Study. Am. J. Clin. Nutr. 2019, 110, 169-176. [CrossRef]

67. Oleforuh-Okoleh, V.U.; Chukwu, G.C.; Adeolu, A.I. Effect of ground ginger and garlic on the growth performance, carcass quality and economics of production of broiler chickens. Glob. J. Bio-Dcience Biotechnol. 2014, 3, 225-229.

68. Karangiya, V.K.; Savsani, H.H.; Patil, S.S.; Garg, D.D.; Murthy, K.S.; Ribadiya, N.K.; Vekariya, S.J. Effect of dietary supplementation of garlic, ginger and their combination on feed intake, growth performance and economics in commercial broilers. Veterinary World 2016, 9, 245-250. [CrossRef]

69. Mohammed, A.A.; Yusuf, M. Evaluation of ginger (Zingiber officinale) as a feed additive in broiler diets. Livest. Res. Rural Dev. 2011, 23, 202. Available online: http://www.lrrd.org/lrrd23/9/moha23202.htm (accessed on 4 November 2015).

(C) 2020 by the authors. Licensee MDPI, Basel, Switzerland. This article is an open access article distributed under the terms and conditions of the Creative Commons Attribution (CC BY) license (http://creativecommons.org/licenses/by/4.0/). 